\title{
Foreign Language Anxiety: Translating and Validating a Scale
}

\author{
Murad M. Al-Shboul ${ }^{1}$ \\ ${ }^{1}$ Department of English, College of Science and Humanities at Howtat Sudair, Majmaah University, \\ AL-Majmaah 11952, Saudi Arabia \\ Correspondence: Murad M. Al-Shboul, Department of English, College of Science and Humanities at Howtat \\ Sudair, Majmaah University, AL-Majmaah 11952, Saudi Arabia. E-mail: m.alshboul@mu.edu.sa
}

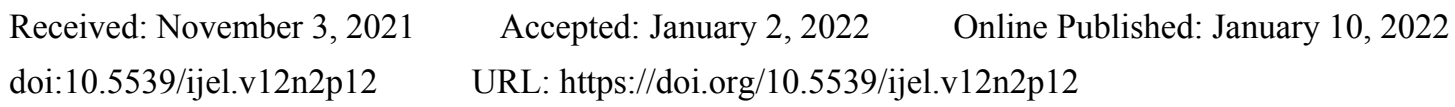

\begin{abstract}
The purpose of this study was to validate one of the most frequently used tools for assessing anxiety associated with foreign languages. The researcher translated it into Arabic because there was no Arabic literature on such an instrument. To achieve the goal, a committee approach was followed (Brislin, 1980) to ensure the validity of the translation. A sample of 102 students was purposefully selected from International Islamic University Malaysia. The instrument consists of 33 items to measure communication apprehension, test anxiety, and fear of negative evaluation. A Principal Component Analysis (PCA) was run to validate the instrument; initially, the PCA produced ten-factor solutions, accounting for $71 \%$ of the total variance explained. However, the last nine factors had only two or three loadings each, and they had cross-loading as well. Therefore, only one factor was used in the final, which accounted for $51 \%$ of the total variance. The researcher took this factor due to its importance for the Arabic literature, which is also in need of a valid instrument to measure communication apprehension. Due to the lack of convergent validity in the other items, the researcher suggests validating the original instrument.
\end{abstract}

Keywords: foreign language, anxiety, communication apprehension, test anxiety, fear of negative evaluation

\section{Introduction}

Anxiety in learning a foreign language has been one of the factors worth investigating over the last three decades, particularly by researchers who have emphasized the importance of effective variables in the learning process (Krahnke \& Krashen, 1983). Horwitz, Horwitz and Cope (1986) designed an instrument that focuses on the anxiety of students studying a foreign language in the classroom. They formed a support group of students who were having difficulty studying languages as part of their study. They created a five-point Likert scale with 33 items based on the students' reported experiences, with the goal of examining students' anxiety while learning a foreign language in the context of a classroom.

According to Horwitz et al. (1986), there are three main sources involved in learning a foreign language; communication apprehension, text anxiety, and fear of negative evaluation. Communication apprehension is defined by Horwitz et al. as "a type of shyness characterized by fear or anxiety about communication with people". The majority of the research in this area was based on McCroskey's conceptualization of communication apprehension as "an individual's level of fear or anxiety associated with either real or anticipated communication with another person or persons" (McCroskey, 1977). It might be limited to a few sittings, such as public speaking, or it could be found in almost all ordinary communication scenarios. In our daily lives, communication is crucial. We communicate most of the time in a variety of ways, like teaching and socializing in different settings such as family, school, and society. As learners in schools and universities, we spend much of our time where oral communication is seen as necessary and demanded as a personal characteristic (daly, 1991). Most students express that they feel nervous when they speak. This feeling of anxiety most often comes because of language anxiety (McCrosky, 1977). This component is especially essential since the Arabic literature lacks a suitable scale to evaluate communication apprehension, and studies that have been conducted are scarce due to the lack of a valid instrument to assess communication apprehension. Test anxiety, the second element, is a sort of performance anxiety that stems from a fear of failure, as stated by Horwitz et al. (1986). It's also worth noting that the most vulnerable pupils are the ones that are subjected to oral testing. The last factor; fear of negative evaluation, is a continuation of the second aspect of foreign language anxiety (test anxiety) because it is not confined to test-taking situations; it may happen in any social or evaluative circumstance, such as speaking in front of a group of students. Horwitz et al. (1986) believe that communication apprehension, test anxiety, and 
fear of negative evaluation provide useful conceptual building blocks for a description of foreign/second language anxiety.

The uniqueness of this experience compared to other academic anxieties is the distinctive needs in the context. On the one hand, learners always need to communicate by means of a tool that they know only imperfectly, and which very probably causes a feeling of insecurity. On the other hand, the difficulties perceived in the attempts at communication are likely to call into question the concept of the individuals as competent communicators and be translated by their conscience, their fear, or their reluctance. The awareness of the pupils is generally associated with their concern about not being able to convey an image of themselves that corresponds to their true personality (Stroud \& Wee, 2016). All of these factors appear to imply that language classrooms, due to their participatory character and constant demands for contact with pupils, may be more stressful than other educational settings. Indeed, instructors and students frequently see oral communication in a foreign language as a larger source of concern than other language abilities (Horwitz et al., 1986).

Although psychological terms have mainly been used to describe the sensations associated with the phenomenon, it should also be taken into account that the anxious experience often presents physiological manifestations such as a feeling of cold, altered respiratory rhythms, and increased rhythm cardiac, sweating or behavioral manifestations such as ringing, stammering, stammering, giving short answers, joking, giggling, or avoidance responses. In addition, it should also be considered that both physiological and behavioral manifestations may differ from one pupil to another or even be triggered by stimuli other than anxiety. (McCroskey, 1977; Scovel, 1978).

In this study, the researcher is interested in translating a scale of foreign language classroom anxiety that has been shown to have an acceptable reliability of 0.9 in the majority of studies that have utilized it. Due to the lack of an Arabic version of the scale known to the researcher, a key focus of the study was the development of an Arabic translation and piloting of a new instrument.

The primary goal of the study is to validate the translated version. Therefore, the study served as the basis for the development of a rating scale that would produce valid and reliable scores for assessing Arabic speaking anxiety.

\section{Methodology}

The research instrument used for this study was a translated version of the FLCAS designed by Horwitz et al. (1986). The researcher was motivated to translate and validate this measure for two reasons. First, this scale was developed based on extensive qualitative research, making it one of the most thorough and reliable measures for assessing situational anxiety in a foreign language classroom. Second, the scale had demonstrated satisfactory reliability coefficients with the first samples of the population to which it had been administered (Horwitz, 1996; Horwitz et al., 1986). In fact, it is presently the most commonly used scale in numerous research projects with comparable objectives.

Following the selection of the FLCAS, which has 33 items, it was translated into Arabic and tested in a pilot study. A committee approach was followed to ensure the validity of the translated version (Brislin, 1980). The questionnaire was translated from English into Arabic by two Ph.D. students at the International Islamic University Malaysia. Both Ph.D. students have linguistics backgrounds and are fluent in Arabic and English. (See Appendix A for the Arabic version). The researcher then sent the updated Arabic language questionnaire to another specialist in both languages and asked him to translate it back into English. It was then compared to the original English version and found to be almost identical. Later on, the Arabic version was distributed to 111 students (female and male) who were studying at the International Islamic University Malaysia, specializing in teaching Arabic to non-Arab speakers. The number of valid questionnaires was 102. However, the typical sample size required is 165 students. After choosing the purposeful sampling, the data was keyed in and revealed that the Arabic version of the questionnaire demonstrated satisfactory reliability with this group of subjects, as measured by Cronbach's alpha coefficient, which was .895 for the whole items.

Using the principal component analysis of the responses of the Arabic version of FLCAS collected from 102 students, the study produced an initial 10 -factor solution, accounting for $71 \%$ of the total variance explained. However, the last nine factors had only two or three items loaded on them, and they had cross-loading. Therefore, only a one-factor solution was used in the final because most of the 33 items loaded substantially on the one factor and this factor was interpretable. Items were assigned to factors based on the highest loadings (a minimum acceptable loading of 40 was set).

The measurement yielded a factor with statistically significant loadings; the smallest value was .55. The inter-factor correlations, moreover, were weak and of no practical importance, ranging from less than .10 
because they were not appearing in the system. To establish the anxiety level of the foreign language scale, the 33 items of the translated instrument were administered to only one factor, which is communication apprehension, while the other factors were not validated. However, they all reported high reliability.

\section{Result}

The initial result showed that there were ten factors measured by the data. The Kaiser-Meyer-Olkin Measure of Sampling Adequacy was .733, p .000, and explained $71.7 \%$ of the variance. A rotated factor matrix is presented in Table 1. The reliability reported using Cronbach's alpha formula was .895 for the whole items, while the final result showed that there was only one factor measured by the data, the Kaiser-Meyer-Olkin Measure of Sampling Adequacy $(\mathrm{p}=.000)$. The rotated factor matrix is presented in Table 2 . The factor includes 8 items with a loading exceeding .40 and explains $51.6 \%$ of the variance. Using Cronbach's alpha formula, the reliability reported was .864 for the whole factor, which is under the name of communication apprehension. Also, as it is shown in Table 2, the reliability of item seven was .865 ; item ten was .848 , item thirteen was .856 , item twenty was .838 , item twenty-one was .850 , item twenty-six was .836 , item twenty-seven was .838 , and the reliability of item thirty-three was .845 . The content of this factor with its translation is shown in Table 3.

Table 1. The initial factor matrix after varimax rotation to translated version for Foreign Language Classroom Anxiety Scale

\section{Component Matrix ${ }^{\mathrm{a}}$}

\begin{tabular}{|c|c|c|c|c|c|c|c|c|c|c|}
\hline & \multicolumn{10}{|c|}{ Component } \\
\hline & 1 & 2 & 3 & 4 & 5 & 6 & 7 & 8 & 9 & 10 \\
\hline a1 & .516 & -.014 & -.325 & -.357 & .021 & .150 & .016 & .000 & -.182 & -.179 \\
\hline a2 & .071 & .226 & .171 & .040 & .631 & .028 & .319 & -.230 & .060 & .150 \\
\hline a3 & .521 & .012 & -.263 & -.216 & -.127 & .204 & .458 & .294 & .055 & -.218 \\
\hline a4 & .436 & .224 & .311 & -.337 & -.222 & -.123 & .357 & .150 & -.236 & .247 \\
\hline a5 & .051 & .479 & .404 & .040 & .500 & -.052 & -.259 & .276 & -.101 & -.018 \\
\hline a6 & .438 & -.269 & .137 & -.159 & .266 & .365 & -.056 & -.144 & -.237 & -.232 \\
\hline a7 & .568 & -.120 & .065 & -.256 & -.031 & -.204 & -.024 & -.149 & .376 & .307 \\
\hline a8 & .423 & -.017 & -.373 & -.015 & .305 & .189 & -.356 & .298 & -.069 & .174 \\
\hline a9 & .446 & .149 & .192 & -.483 & .058 & .230 & -.283 & -.050 & .251 & -.018 \\
\hline a10 & .658 & .073 & -.288 & -.087 & .194 & -.131 & -.172 & -.235 & .035 & -.247 \\
\hline a11 & .225 & .467 & .431 & -.030 & .141 & -.174 & .137 & .133 & .328 & -.093 \\
\hline a12 & .373 & .442 & .163 & .146 & -.381 & .153 & .211 & -.124 & .178 & .145 \\
\hline a13 & .675 & .044 & -.044 & -.093 & -.049 & .244 & .060 & .067 & .342 & -.161 \\
\hline a14 & .085 & .478 & .405 & .167 & .284 & .256 & .142 & .340 & -.064 & -.002 \\
\hline a15 & .230 & -.278 & .361 & .495 & -.323 & .207 & -.108 & .105 & .115 & -.032 \\
\hline a16 & .441 & -.480 & .232 & .107 & .282 & -.392 & -.027 & -.085 & .213 & -.070 \\
\hline a17 & .391 & -.496 & .126 & .234 & .160 & .185 & .187 & .133 & -.022 & -.158 \\
\hline a18 & .411 & .483 & -.012 & .390 & -.134 & .064 & -.082 & -.235 & -.006 & -.083 \\
\hline a19 & .602 & .161 & -.074 & .018 & -.077 & -.512 & .130 & .148 & -.207 & -.207 \\
\hline $\mathrm{a} 20$ & .700 & .149 & -.240 & -.016 & -.015 & -.316 & -.181 & .216 & .112 & .018 \\
\hline $\mathrm{a} 21$ & .638 & .010 & -.179 & .037 & -.106 & .164 & -.159 & .210 & -.003 & .441 \\
\hline $\mathrm{a} 22$ & .480 & .008 & -.224 & .414 & .311 & .213 & .289 & -.215 & -.009 & .133 \\
\hline $\mathrm{a} 23$ & .561 & -.432 & .017 & .166 & .114 & -.091 & .079 & -.014 & .063 & .409 \\
\hline $\mathrm{a} 24$ & .564 & .367 & .246 & -.056 & -.212 & -.121 & -.064 & -.009 & -.421 & .098 \\
\hline $\mathrm{a} 25$ & .454 & .386 & -.102 & .496 & .035 & -.132 & -.253 & -.054 & -.048 & -.058 \\
\hline $\mathrm{a} 26$ & .745 & -.011 & -.217 & -.076 & .063 & -.171 & .106 & -.087 & -.137 & -.116 \\
\hline a27 & .763 & -.054 & -.156 & .191 & .007 & -.096 & .205 & -.077 & .044 & -.115 \\
\hline $\mathrm{a} 28$ & .541 & .419 & .012 & -.347 & -.121 & .221 & -.126 & -.258 & .067 & -.009 \\
\hline a29 & .467 & -.346 & .356 & .285 & -.236 & .018 & -.125 & .257 & .079 & -.248 \\
\hline a30 & .547 & -.427 & .329 & -.317 & .006 & -.007 & -.075 & .136 & .076 & -.019 \\
\hline a31 & .543 & -.485 & .308 & -.090 & .055 & .016 & -.010 & -.078 & -.365 & .193 \\
\hline $\mathrm{a} 32$ & .286 & -.064 & .688 & -.011 & -.135 & .037 & -.126 & -.395 & -.139 & -.097 \\
\hline a33 & .671 & .031 & -.291 & .302 & -.137 & .167 & -.084 & -.042 & -.080 & .086 \\
\hline
\end{tabular}


Table 2. The final factor matrix after varimax rotation to translated version for Foreign Language Classroom Anxiety Scale

\begin{tabular}{lll} 
Component Matrix $^{\mathrm{a}}$ & \\
\cline { 2 - 3 } Item No. & Component & Cronbach's Alpha for each item \\
\hline & 1 & \\
7 & .550 & .865 \\
10 & .712 & .848 \\
13 & .639 & .856 \\
20 & .786 & .838 \\
21 & .687 & .850 \\
26 & .787 & .836 \\
27 & .805 & .838 \\
33 & .747 & .845 \\
\hline Extraction Method: Principal Component Analysis. & The overall reliability coefficient is .864 \\
\hline
\end{tabular}

Table 3. The content of the factor which measures communication apprehension in foreign language classroom anxiety scale with its translation

\begin{tabular}{|c|c|c|}
\hline Item No. & The original item & The translated item \\
\hline 7 & $\begin{array}{l}\text { I keep thinking that the other students are better at languages than I } \\
\text { am }\end{array}$ & افكر دائما ان الطلاب الآخرين افضل مني باللغة العربية \\
\hline 10 & I worry about the consequences of failing my foreign language class & انا قلق بشان فشل منعاقب عند تحدثي اللغة العربية في المحاضرة \\
\hline 13 & It embarrasses me to volunteer answers in my language class & العربية بالاحر اج عندما يكون هناك اجابات كثيرة يقدمها الطلاب في محاضرة اللغة \\
\hline 20 & $\begin{array}{l}\text { I can feel my heart pounding when I'm going to be called on in } \\
\text { language class }\end{array}$ & اشعر بضربات قلبي عندما يتوجب علي التحدث في محاضرة اللغة العربية \\
\hline 21 & The more I study for a language test, the more confused I get & عندما ادرس لامتحان اللغة العربية اكثر اشعر بارتباك اكثر \\
\hline 26 & $\begin{array}{l}\text { I feel more tense and nervous in my language class than in my other } \\
\text { classes }\end{array}$ & اشعر بتوتر وقلق في محاضرة اللغة العربية اكثر من اي محاضرة اخرى \\
\hline 27 & I get nervous and confused when I am speaking in my language class & ينتابني قلق و اضطر اب عندما اتحدث في محاضرة اللغة العربية \\
\hline 33 & $\begin{array}{l}\text { I get nervous when the language teacher asks questions which I } \\
\text { haven't prepared in advance }\end{array}$ & اشعر بقلق عندما بسأل مدرس اللغة العربية اسئلة لم اكن مستعدا لها من قبل \\
\hline
\end{tabular}

\section{Conclusion}

Since the first concern of the study was to translate the scale into Arabic due to the lack of Arabic literature on such a scale, to measure the foreign language anxiety in the classroom. The scale was translated accurately by a committee approach. The scale demonstrated satisfactory reliability with the group of subjects as measured by Cronbach's alpha coefficient, which was .895 for the whole items. That means the translated items are good for measuring language anxiety for students who are learning Arabic as a foreign language in terms of reliability, which refers to the degree to which a survey instrument consistently measures whatever it intends to be measured (Creswell, 2012). Therefore, the measurement instrument is consistent and accurate since it has a high degree of reliability (Mueller, 1986). While in terms of face validity and convergent validity, as the researcher stated in his study (validation), according to face validity, all 33-items are valid to measure what is supposed to be measured. Light, Singer, and Willet (1990) stated that the way to measure face validity is "by having experts examine the measure and agree that it does assess what it is supposed to assess." The measure "looks right, reads right, and feels right" (p. 152). The current measure has the component as indicated by a doctor at IIUM specializing in Arabic language teaching. Due to the importance of convergent validity, which refers to the degree to which the latent variables correlate with each other, the researcher chose the only factor that measures what is supposed to measure its direction. The factor measures communication apprehension, and since the Arabic literature also does not have any scale to measure this component, the study adds a valid instrument to the Arabic literature to measure communication apprehension in light of the only factor solution, whereas the other items do not have convergent validity to measure what is supposed to be measured. This suggests that the original instrument needs to have convergent validity since it is the most frequently used instrument to measure foreign language anxiety. 


\section{References}

Brislin, R. W. (1980). Translation and content analysis of oral and written materials. In H. C. Triandis \& J. W. Berry (Eds.), Handbook of cross-cultural psychology.

Creswell, J. W. (2012). Educational research: Planning, conducting, and evaluating quantitative and qualitative research. Educational Research, 4.

Horwitz, E. K. (1996). Even teachers get the blues: Recognizing and alleviating language teachers' feelings of foreign language anxiety. Foreign Language Annals, 29(3), 365-372. https://doi.org/10.1111/j.1944-9720.1996.tb01248.x

Horwitz, E. K., Horwitz, M. B., \& Cope, J. (1986). Foreign Language Classroom Anxiety. The Modern Language Journal, 70(2), 125-132. https://doi.org/10.1111/j.1540-4781.1986.tb05256.x

Krahnke, K. J., \& Krashen, S. D. (1983). Principles and Practice in Second Language Acquisition. TESOL Quarterly, 17(2). https://doi.org/10.2307/3586656

Light, R. J., Singer, J. D., \& Willett, J. B. (1990). By design: Planning research on higher education (p. 272). Retrieved from https://www.hup.harvard.edu/catalog.php?isbn=9780674089310

McCroskey, J. C. (1977). Oral Communication Apprehension: A Summary of Recent Theory and Research. Human Communication Research, 4(1), 78-96. https://doi.org/10.1111/j.1468-2958.1977.tb00599.x

Scovel, T. (1978). The Effect of Affect on Foreign Language Learning: A Review of the Anxiety Research. Language Learning, 28(1), 129-142. https://doi.org/10.1111/j.1467-1770.1978.tb00309.x

Stroud, C., \& Wee, L. (2016). Anxiety and Identity in the Language Classroom. RELC Journal, 37(3), 299-307. https://doi.org/10.1177/0033688206071311

\section{Appendix A}

\begin{tabular}{|c|c|c|c|c|c|c|}
\hline غير مو افق & غير مو افق & محايد & مو افق & 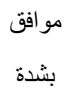 & 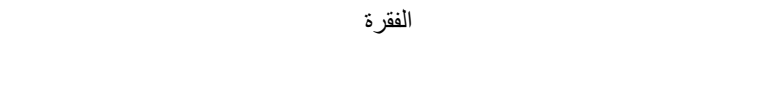 & الرقم \\
\hline & & & & & انشعر بالضعف عندما اتحدث اللغة العربية في المحاضرة & 1 \\
\hline & & & & & لا اشعر بالقلق عند ارتكابي الاخطاء باللغة العربية في المحاضرة & 2 \\
\hline & & & & & اشعر بارنعاش عندما استدعى للتحدث في محاضرة اللغة العربية & 3 \\
\hline & & & & & اشعر بالتوتر عندما لا افهم ماذا يقول المدرس في محاضرة اللغة العربية & 4 \\
\hline & & & & & لا اقلق ابدا عند تسجيلي مواد اللغة العربية & 5 \\
\hline & & & & & في محاظرة اللغة العربية اجد نفسي افكر باشياء بعيدة عن المساق & 6 \\
\hline & & & & & افكر دائما ان الطلاب الآخرين افضل مني باللغة العربية & 7 \\
\hline & & & & & انا دائما آخذ الامور ببساطة خلال امتحانات اللغة العربية & 8 \\
\hline & & & & & اصاب بالذعر عندما يتوجب علي ان اتحدث بدون تحضير في محاضرة اللغة العربية & 9 \\
\hline & & & & & انا قلق بشان فثل متعاقب عند تحدثي اللغة العربية في المحاضرة & 10 \\
\hline & & & & & لاداعي ان يقلق الطلاب كثير ا من محاضر ات اللغة العربية & 11 \\
\hline & & & & & اثعر بعدم ارتياح وبالعصبية عندما انسى اثياء اعرفها في محاضر ات اللغة العربية & 12 \\
\hline & & & & & انشعر بالاحر اج عندما يكون هناك اجابات كثيرة يقدمها الطلاب في محاضرة اللغة العربية & 13 \\
\hline & & & & & لا اشعر بالقلق عند التحدث باللغة العربية مع العرب المتحدثين بها & 14 \\
\hline & & & & & اشعر بالقلق عندما لا افهم ماذا يصحح المدرس في المحاضرة & 15 \\
\hline & & & & & اشعر بالقلق في محاضر ات اللغة العربية حتى عندما اكون على استعداد تام & 16 \\
\hline & & & & & اشعر غالبا اني لا احب محاضرات اللغة العربية & 17 \\
\hline & & & & & اشعر بثقة عندما اتحدث اللغة العربية بالمحاظر في المحاضرة & 18 \\
\hline & & & & & اشعر بالخوف عندما تكون لغة المدرس تؤهلة لتصحيح اي خطأ باللغة العربية & 19 \\
\hline & & & & & اشعر بضربات قلبي عندما ينوجب علي التحدث في محاضرة اللغة العربية & 20 \\
\hline
\end{tabular}




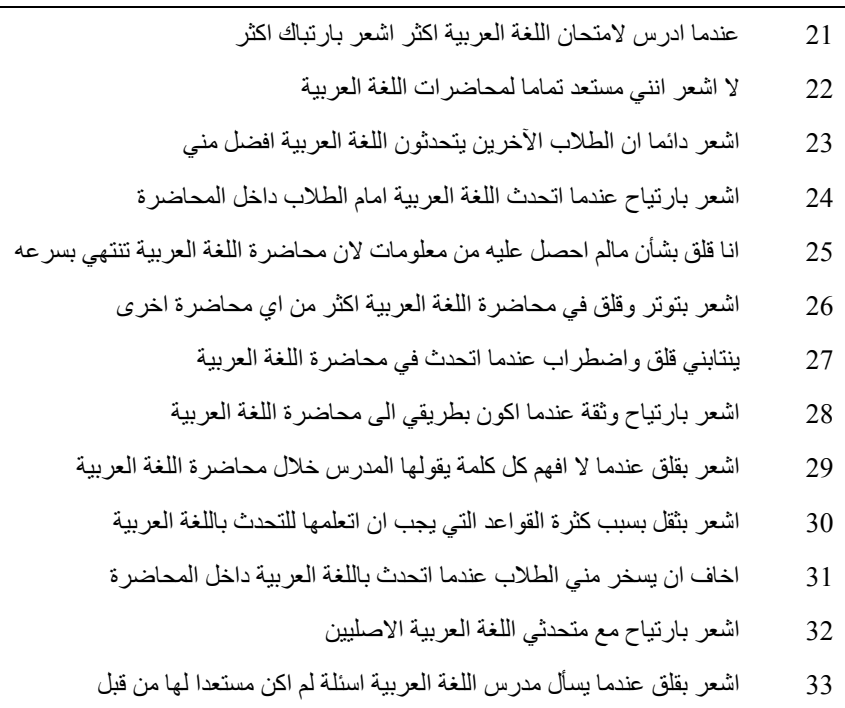

\section{Copyrights}

Copyright for this article is retained by the author, with first publication rights granted to the journal.

This is an open-access article distributed under the terms and conditions of the Creative Commons Attribution license (http://creativecommons.org/licenses/by/4.0/). 